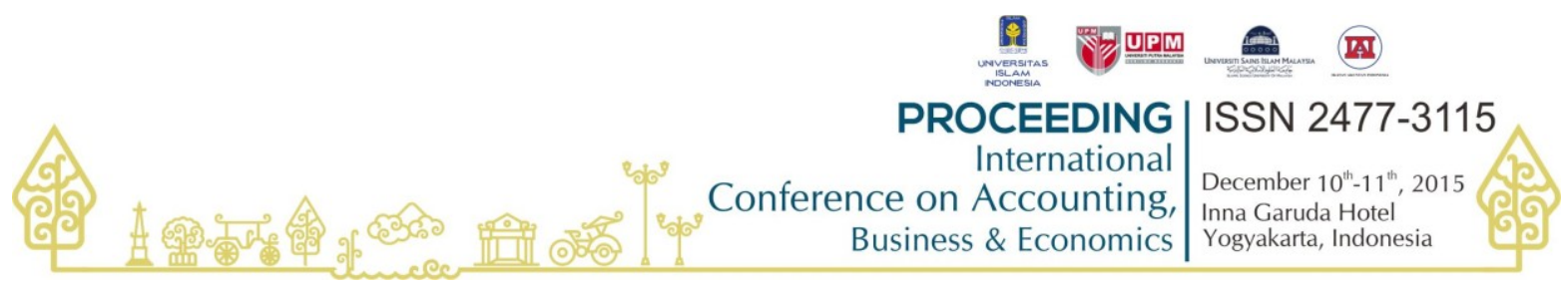

\title{
The existence of soybean farmers and market in Solok regency
}

\author{
Hasdi Aimon, Melti Roza Adry, Elida \\ Universitas Negeri Padang \\ (aimon_55@yahoo.co.id)
}

\begin{abstract}
This study aims to look at the existence of soybean farmers and markets in Solok Regency. This study was conducted in Solok Regency to 200 households. This study was analyzed using descriptive analysis that aims to see the level of consumer preferences to processed soy products in Solok Regency. Furthermore, inductive analysis was analyzed using multiple linear regression analysis with OLS method that aims to look at the determinants of the demand for processed soy products in Solok Regency. The study shows that (1) the processed soy products most in demand by the society in Solok Regency are tofu and tempeh. (2) The number of household members, education of wife and job sector of husband affect significantly on the demand for tempeh in Solok Regency, while income, marital status, education of husband and job sector of wife do not affect significantly on the demand for tempeh in Solok Regency. (3). The number of household members and job sector of husband affect significantly on the demand for tofu in Solok Regency, while income, marital status, education of husband, education of wife and job sector of wife do not affect significantly on the demand for tofu in Solok Regency.
\end{abstract}

Keywords: Consumer Preferences, Demand, Soy

\section{FOREWORD}

Soybean is a plant that originated from Manchuria and parts of China where there are many types of wild soybean. Then, it spread to tropical and subtropical areas. After breeding, many types of superior soybeans produced were cultivated. The harvesting age of soybean plants varies depending on the variety but generally range between 75 and 105 days.

In terms of food and nutrition, soybean is the most inexpensive source of protein in the world, in addition to producing oils with good quality. The varieties of soybean that exist in Indonesia include Otau, Ringgit, Sumbing, Merapi, Shakti, Davros, Taiching, TK-5, Orba, Galunggung, Lokon, Guntur, and others, have a protein content of 30,53 until 44 percent while fat content of 7,5 until 20,9 percent.

Currently, the demand for soybean experiences an increase. This is because soybean has many benefits. Increase in the demand for soybean causes the producers to increase the number of soybean production. On the other hand, the production of local soybean has a decrease; this is caused by the lack of interest of farmers to grow soybeans in addition to the insufficient land to cultivate them. Therefore, to meet the uncontrollable demand for soybeans, the government imports soybeans. This is exactly what caused the dependence of imported soybean in Indonesia higher.

This is supported by the study of Aimon et al (2013) that showed that various problems were faced by soybean farmers in Solok Regency. The problems ranged from problems of capital, production process, harvest and post-harvest as well as government policy issues. Postharvest problem faced by soybean farmers in Solok Regency was the relatively low selling price of soybean which caused the profit obtained by farmers relatively small. As a result, soybean farmers chose to grow other crops resulting in the decline of soybean production. Furthermore, 
the production of local soybean also could not meet the local demand, hence triggering the increase of soybean import into the country. This condition is actually an opportunity to increase the production of soybean with better quality so it can meet local demand.

In addition, to resolve the problems of post-harvest it is necessary for creation of new home industries in order to increase added value of soybeans as well as increasing the economy of families of soybean farmers. Moreover, these activities can create soy product differentiation (product differentiation) so it has added value economically with a high quality of output with regards to downstream industries/home industries as user of soybean as raw material of the industry, as well as making them as new home industries. Furthermore, the market response on the demand for processed soy products in Solok Regency needs to be seen in advance.

This article aims to look at the consumer preferences to processed soy products in Solok Regency and the determinants of the household demand for processed soy products in Solok Regency.

\section{LITERATURE REVIEW}

\section{Demand}

According to Case and Fair (2007), demand is the quantity of goods/services that consumers are requesting or willing to purchase at a certain price level. The demand curve is a curve/graph that illustrates the relationship pattern between quantity of goods/services requested by consumers and the price level.

Demand Function is a function that states the relationship between price and quantity of goods/services requested or purchased by consumer, if the other variables remain constant [ceteris paribus]. Formula:

$$
\mathrm{Qd}=\mathrm{f}(\mathrm{Px}, \mathrm{Y}, \mathrm{Py})
$$

Where Qd is the quantity of demand for goods, Px is the price of the goods in question, $\mathrm{Y}$ is the income and Py is the price of substitute goods.

Asumption: only the price variable of the goods is considered, while other variables are assumed constant [ceteris paribus], hence the above formula becomes: $Q d=f(P)$ or $P=f(Q d)$.

In the theory of demand, price affects negatively on demand, while price of other goods and income affect positively on the demand for goods and services. Graphically the influence of prices of other goods and income can be seen in Figure 1.

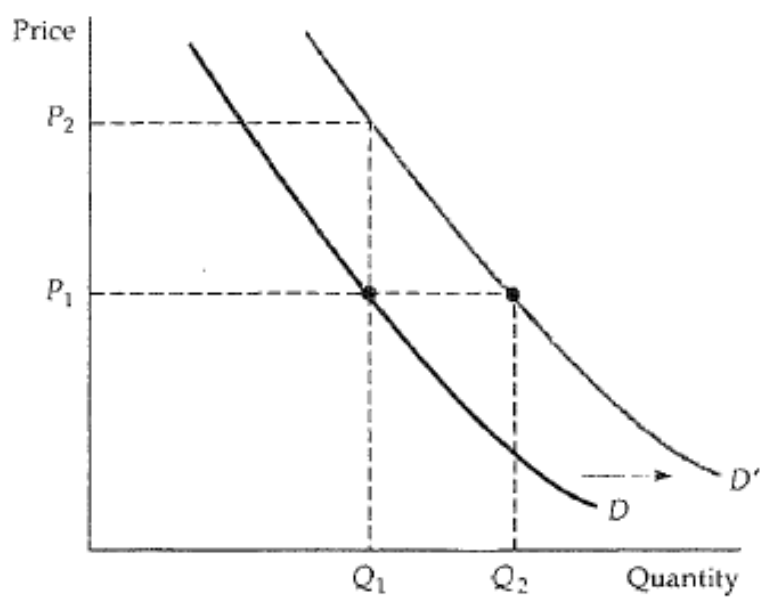

Figure 1: Shift of Demand Curve 
Figure 1 shows that when income increases it will lead to the demand for goods and services, thereby causing the demand curve to move from $D$ to $\mathrm{D}^{\prime}$. Meanwhile, if the income of the society decreases then the demand curve will shift to bottom left; so is the case with the prices of other goods.

\section{METHOD OF STUDY}

\section{Focus of study}

The study of economic empowerment of soybean farmers is focused on the development of new home industries that can accommodate production of soybean that can be used as raw material for the industries, thereby able to increase the added value of soybean and improve the welfare of soybean farmers in Solok Regency. Therefore, it is necessary to conduct study on how the consumer preferences to the processed soy products in Solok Regency.

\section{Method and place of study}

This study used a survey method to the consumers of processed soy products that exist in Solok Regency and experimental method to the soybean farmers in the center of soybean production located in Solok Regency.

\section{Population and sample}

This study is included in survey study method. The determination of sample in this study used purposive sampling technique where the determination of number of samples is adjusted with the purpose of the study. The number of consumers of soybean in Solok Regency could not be known with certainty. Therefore, the researchers determined a certain period of time to determine the number of samples taken in this study. Based on the study conducted, the researchers surveyed 200 households in Solok Regency.

\section{Data and source of data}

Data in this study consists of primary data and secondary data. The primary data was obtained directly from the main sources, namely the consumers of soybean and the households of soybean farmers in Solok Regency, as well as the home industries that use raw material of soybean as the main raw material of their products and the bureaucracy in Jorong, District and Regency. Meanwhile, the secondary data was obtained from literature review and related institutions that can support this study. The implementation of this study referred to the information of agricultural statistical data in Solok Regency, results of the previous studies, and data obtained in the field.

\section{Technique of data analysis}

Data analysis was performed by descriptive quantitative and qualitative through the approach of economic concepts from various aspects, and also adapted to the condition of physic and economic, as well as government policy. To see the demand of society for the processed soy products, multiple linear regression analysis was used by using several variables of demand function that can be seen from the consumer preferences in Solok Regency.

The demand model used is:

$$
\log Q=b_{0}+b_{1} \log (\operatorname{Inc})+b_{2} \text { Pop }+b_{3} \text { Married }+b_{4} E D U H
$$




$$
+b_{5} E D U W+b_{6} S P U H+b_{7} S P U W+e
$$

Where $\mathrm{Q}$ is the demand for processed soy products, Inc is the income of the household, Pop is the number of household members, Married is the marital status of the household head, EDUH is the last education of the husband, EDUW is the last education of the wife, SPUH is the job sector of the husband and SPUW is the job sector of the wife.

More details can be seen in the following table:

Table 1: Operational Definition

\begin{tabular}{|c|c|}
\hline Variable & Definition \\
\hline 1. Demand (Q) & $\begin{array}{l}\text { Household demand for processed soy products } \\
\text { measured in } \mathrm{kg}\end{array}$ \\
\hline 2. Income (inc) & Total income obtained by household per month \\
\hline 3. Married & $\begin{array}{l}\text { Marital status of the household head } \\
\text { 1. Married } \\
\text { 0. Others }\end{array}$ \\
\hline 4. EDUH & Last education of husband measured in years \\
\hline 5. EDUW & Last education of wife measured in years \\
\hline 6. SPUH & $\begin{array}{l}\text { Job sector of husband with following category: } \\
\text { 1. Formal } \\
0 \text {. Others }\end{array}$ \\
\hline 7. SPUW & $\begin{array}{l}\text { Job sector of wife with following category: } \\
\text { 1. Formal } \\
0 . \text { Others }\end{array}$ \\
\hline
\end{tabular}

\section{RESULT AND DISCUSSION}

\section{Consumer preferences}

Consumer preference is a choice to like or dislike by someone to consumed products (goods or services). Consumer preference shows consumer liking from a wide variety of products available. This study looks at the consumer preferences to the processed soy products in Solok Regency.

Table 2:

Consumer Preferences to Processed Soy Products in Solok Regency

\begin{tabular}{lccccc}
\hline \multirow{2}{*}{ PREFERENSI } & \multicolumn{5}{c}{ TAHU } \\
\cline { 2 - 6 } & Tempe & Tauco & $\begin{array}{c}\text { Susu } \\
\text { Kedelai } \\
\text { Cair }\end{array}$ & $\begin{array}{c}\text { Tepung } \\
\text { Kedelai }\end{array}$ & $\begin{array}{c}\text { Kembang } \\
\text { Tahu }\end{array}$ \\
\cline { 2 - 6 } & 0.00 & 0.50 & 1.01 & 1.51 & 1.09 \\
TIDAK SUKA & 4.52 & 2.01 & 4.02 & 3.02 & 3.80 \\
KURANG SUKA & 57.29 & 30.65 & 31.16 & 12.56 & 10.33 \\
SAMA-SAMA SUKA & 30.65 & 50.75 & 49.75 & 56.78 & 47.83 \\
SUKA & 7.54 & 16.08 & 14.07 & 26.13 & 36.96 \\
SANGAT SUKA & 100.00 & 100.00 & 100.00 & 100.00 & 100.00 \\
\hline JUMLAH & 3.40 & 3.78 & 3.70 & 4.01 & 3.83 \\
\hline RATA - RATA & & & & & \\
JAWABAN & & & & & \\
RESPONDEN & &
\end{tabular}


Table 2 shows that there are no respondents who dislike tofu, 4,52 percent of respondents are less fond of tofu compared with tempeh. Respondents prefer tofu and tempeh compared with other processed soy products. Respondents equally like tofu and tempeh which can be seen from the consumer preference to tofu and tempeh of 57,29 percent. In addition, 30,65 percent of respondents like tofu more than tempeh, and only 7,54 percent of respondents who really like tofu compared with tempeh. Furthermore, this is also shown by the amount of budget spent by households to buy tofu and tempeh compared with other processed soy products. In average all households buy these two products for consumption. Additionally, based on the average answer of respondents, a value of 3,40 percent was obtained; this means that the respondents in Solok Regency equally like tofu and tempeh.

Moreover, judging from consumer preferences to the choice of tofu and tauco, only 0.50 percent of respondents who dislike tofu but really like tauco and 2.01 percent are less fond of tofu but like tauco, while 30,65 percent equally like tofu and tauco. Nevertheless, 50.75 percent of respondents like tofu and are less fond of tauco and only 16.08 percent of respondents really like tofu and dislike tauco. By looking at the average value of 3,78 this means that the respondents like tofu more than tauco.

Furthermore, judging from consumer preferences to the choice of tofu and liquid soy milk, soy flour and beancurd, the respondents like tofu more dominantly than liquid soy milk, soy flour and beancurd with an average value each of 4 . Therefore, it can be concluded that in overall the consumers in Solok Regency equally like tofu and tempeh but prefer tofu compared with tauco, liquid soy milk, soy flour and beancurd.

Table 3: Consumer Preference to Processed Soy Products in Solok Regency

\begin{tabular}{|c|c|c|c|c|}
\hline \multirow[b]{2}{*}{ PREFERENSI } & \multicolumn{4}{|c|}{ TEMPE } \\
\hline & Tauco & $\begin{array}{c}\text { Susu } \\
\text { Kedelai } \\
\text { Cair }\end{array}$ & $\begin{array}{l}\text { Tepung } \\
\text { Kedelai }\end{array}$ & $\begin{array}{c}\text { Kembang } \\
\text { Tahu }\end{array}$ \\
\hline$\overline{T \text { TIDAK SUKA }}$ & 2.03 & 1.52 & 2.04 & 2.76 \\
\hline KURANG SUKA & 5.58 & 8.12 & 4.59 & 4.42 \\
\hline SAMA-SAMA SUKA & 34.01 & 28.93 & 17.35 & 13.81 \\
\hline SUKA & 48.22 & 50.76 & 59.18 & 50.28 \\
\hline SANGAT SUKA & 10.15 & 10.66 & 16.84 & 28.73 \\
\hline JUMLAH & 100.00 & 100.00 & 100.00 & 100.00 \\
\hline$\overline{\text { RATA - RATA }}$ & & & & \\
\hline $\begin{array}{l}\text { JAWABAN } \\
\text { RESPONDEN }\end{array}$ & 3.54 & 3.56 & 3.77 & 3.60 \\
\hline
\end{tabular}

In addition, when seen from Table 3 about the preference of society on tempeh compared with other products, it appears that the respondents prefer tempeh compared with tauco, soy milk, soy flour and beancurd. This proves that tempeh is the product more in demand by the society in Solok Regency. Out of the five processed soy products, tofu, tempeh and tauco are the more desirable products by the society compared with soy milk, soy flour and beancurd. 
Table 4: Consumer Preference to Processed Soy Products in Solok Regency

\begin{tabular}{|c|c|c|c|c|c|c|}
\hline \multirow[b]{2}{*}{ PREFERENSI } & \multicolumn{3}{|c|}{ TAUCO } & \multicolumn{2}{|c|}{$\begin{array}{c}\text { SUSU KEDELAI } \\
\text { CAIR }\end{array}$} & \multirow{2}{*}{$\begin{array}{c}\text { TEPUNG KEDELAI } \\
\text { Kembang Tahu }\end{array}$} \\
\hline & $\begin{array}{c}\text { Susu } \\
\text { Kedelai } \\
\text { Cair } \\
\end{array}$ & $\begin{array}{l}\text { Tepung } \\
\text { Kedelai }\end{array}$ & $\begin{array}{l}\text { Kembang } \\
\text { Tahu }\end{array}$ & $\begin{array}{l}\text { Tepung } \\
\text { Kedelai }\end{array}$ & $\begin{array}{c}\text { Kembang } \\
\text { Tahu }\end{array}$ & \\
\hline$\overline{\text { TIDAK SUKA }}$ & 14.05 & 13.19 & 12.21 & 14.79 & 16.46 & 20.49 \\
\hline KURANG SUKA & 19.46 & 21.43 & 16.86 & 15.38 & 17.68 & 27.05 \\
\hline SAMA-SAMA SUKA & 24.86 & 15.93 & 16.28 & 16.57 & 11.59 & 18.85 \\
\hline SUKA & 38.38 & 41.21 & 39.53 & 43.79 & 37.80 & 31.15 \\
\hline SANGAT SUKA & 3.24 & 8.24 & 15.12 & 9.47 & 16.46 & 2.46 \\
\hline JUMLAH & 100.00 & 100.00 & 100.00 & 100.00 & 100.00 & 100.00 \\
\hline \multicolumn{7}{|l|}{$\overline{\text { RATA - RATA }}$} \\
\hline JAWABAN & 2.75 & 2.82 & 2.83 & 2.69 & 2.63 & 1.64 \\
\hline RESPONDEN & & & & & & \\
\hline
\end{tabular}

Result of the study shows that the processed soy products most desirable by the society of Solok Regency are tofu and tempeh. The society prefers these two products compared with other processed soy products such as tauco, soy flour, soy milk and beancurd. This means that tofu and tempeh can be used as comestibles of society that are rich in vegetable protein. Additionally, tofu and tempeh can be used as side dishes that can be consumed with rice as staple food. On top of that, the high demand of society for both of these products is due to the relatively low selling price so it can be affordable by the entire society.

This can be seen from the amount of budget spent by households for tofu and tempeh. From 200 respondents, more than 90 percent only allocate budget to buy tofu and tempeh without buying other processed soy products.

Nevertheless, the other processed soy product that is quite attractive to the society is tauco. The use of tauco is only as an ingredient in the making of curry/goulash. However, the use of this product is very small except for breakfast merchants or during religious holidays. Soy flour and soy milk are also food that is not regularly consumed by the society. This means that most of the society is less interested in these processed products; so is the case with beancurd which is very rarely consumed by society.

Based on the consumer preferences, it can be seen that tofu and tempeh are the products more in demand by the society. Thus, the derivation of processed soy products that needs to be developed in Solok Regency is the development of home industries that process soybeans into tofu and tempeh, thereby increasing the added value of soybeans produced by local farmers. Additionally, it can improve the welfare of farmers and resolve the post-harvest problems often faced by farmers. The development of home industry is also expected able to absorb workforce as well as reducing the unemployment rate in rural areas which is identical to the agricultural sector and also reducing poverty. 


\section{Utility of processed soy products}

Table 5: Utility of Tofu and Tempeh

\begin{tabular}{llrrrrr}
\hline & \multicolumn{2}{c}{$\mathrm{q}$ tahu } & \multicolumn{2}{c}{$\mathrm{q}$ tempe } & \multirow{2}{*}{ Total } \\
\cline { 3 - 5 } & & $<3.6$ & $>=3.6$ & \multicolumn{1}{c}{$<$} & \multicolumn{1}{c}{$>=2$} & \\
\hline Utilitas & sangat suka & $3.0 \%$ & $4.5 \%$ & $3.50 \%$ & $4.00 \%$ & $7.50 \%$ \\
& Suka & $15.5 \%$ & $15.5 \%$ & $22.00 \%$ & $9.00 \%$ & $31.00 \%$ \\
& sama-sama & $25.5 \%$ & $31.5 \%$ & & & \\
& suka & & & $16.50 \%$ & $40.50 \%$ & $57.00 \%$ \\
& kurang suka & $4.0 \%$ & $.5 \%$ & $2.50 \%$ & $2.00 \%$ & $4.50 \%$ \\
\hline Total & & $48.0 \%$ & $52.0 \%$ & $44.50 \%$ & $55.50 \%$ & $100.00 \%$ \\
\hline
\end{tabular}

Table 5 shows that in terms of utility, 57 percent of respondents in Solok Regency equally like tofu and tempeh. However, if seen from the amount of consumption of tofu and tempeh, the respondents consume in greater amount than the median value which is $3,6 \mathrm{~kg}$ per month for tofu and above $2 \mathrm{~kg}$ per month for tempeh with each value of 31,5 percent and 40,50 percent.

\section{Demand for processed soy products}

The following is the regression analysis result of the demand of the society for processed soy products in Solok Regency.

Table 6:

Result of Regression Analysis of the Demand for Processed Soy Products

\begin{tabular}{crrrr}
\hline \multicolumn{2}{c}{ TEMPE } & \multicolumn{2}{c}{ TAHU } \\
\hline \hline Variable & Coefficient & Prob. & Coefficient & Prob. \\
\hline \hline LOG(INCOME) & 0.057 & 0.4769 & 0.121 & 0.1749 \\
MARRIED & 0.090 & 0.5650 & 0.045 & 0.7947 \\
POP & 0.101 & $0.0011^{* *}$ & 0.163 & $0.0000^{*}$ \\
EDUH & 0.007 & 0.6952 & -0.011 & 0.5845 \\
EDUW & -0.042 & $0.0288^{* *}$ & -0.0002 & 0.9904 \\
SPUH & -0.311 & $0.0115^{* *}$ & -0.265 & $0.0487^{* *}$ \\
SPUW & 0.078 & 0.5150 & 0.054 & 0.6873 \\
C & -1.545 & 0.1443 & -2.526 & 0.0316 \\
\hline \hline R-squared & 0.1251 & & 0.1575 & \\
F-statistic & 3.7184 & & 5.0734 & \\
Prob(F-statistic) & 0.000873 & & 0.000027 & \\
\hline
\end{tabular}

Description:

* : significant on $\alpha=0,01$

$* *$ : significant on $\alpha=0,05$ 


\section{Classic assumption test}

Based on the classic assumption test, it was obtained that the equation model of multiple linear regression for the demand for tempeh and tofu is free from heteroscedasticity problem. For the regression analysis result for the demand for tofu, the value of Prob. Chi-Square $=0.6450$ was obtained and Prob. Chi-Square $=0.4301$ for the demand for tempeh. Thus, the model is free from the problem of heteroscedasticity.

\section{Multiple linear regression analysis and hypotheses testing on the demand for processed soy products}

\section{Demand for tempeh}

Based on the output from table 6, the regression equation of demand for tempeh is as following:

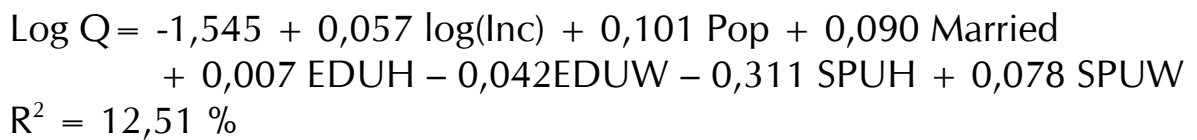

Based on equation 1, it is shown that the income of household affects positively but not significantly on the demand for tempeh in Solok Regency with a regression coefficient of 0,037, which means that an increase in the income of household of 1 percent will increase the demand for tempeh by 0,037 percent.

Moreover, the number of household members affects positively but insignificantly on the demand for tempeh in Solok Regency; if the number of household member increases by one person then it will increase the demand for tempeh by 0,101 percent.

So is the case with marital status; marital status affects positively and significantly on the demand for tempeh in Solok Regency. If a household is married then it will increase the demand for tempeh by 0.090 percent.

Furthermore, the education of husband affects positively but not significantly on the demand for tempeh; if the education of husband increases by 1 year then it will increase the demand for tempeh by 0.007 percent, while the education of wife affects negatively and significantly on the demand for tempeh in Solok Regency. If the education of wife increases by one year then it will decrease the demand for tempeh by 0,042 percent.

Next, the job sector of husband (formal/non formal) affects negatively and significantly on the demand for tempeh in Solok Regency; if the husband works in the formal sector then it will decrease the demand for tempeh by 0,311 percent. Meanwhile, the employment status of wife affects negatively but not significantly on the demand for tempeh in Solok Regency; this means if the wife works in the formal sector then it will increase the demand for tempeh by 0.078 percent.

\section{Demand for tofu}

Based on the output from table 6 , the regression equation of demand for tofu is as following: $\log \mathrm{Q}=-2,526+0,121 \log (\operatorname{Inc})+0,163$ Pop $+0,045$ Married - 0,011 EDUH $-0,002$ EDUW - 0,265 SPUH + 0,054 SPUW

$\mathrm{R}^{2}=15,75 \%$

Based on equation 2, it is shown that the income of household affects positively but not significantly on the demand for tofu in Solok Regency with a regression coefficient of 0,121 , 
meaning that an increase in household income by 1 percent will increase the demand for tofu by 0,121 percent.

Furthermore, the number of household members affects positively and significantly on the demand for tofu in Solok Regency; if the household member increases by one person then it will increase the demand for tofu by 0,163 percent.

Marital status affects positively but not significantly on the demand for tofu in Solok Regency. If a household is married then it will increase the demand for tofu by 0.045 percent.

Moreover, the education of husband affects negatively but not significantly on the demand for tofu; if the education of husband increases by 1 year then it will decrease the demand for tofu by 0.011 percent, and the education of wife affects negatively but not significantly on the demand for tofu in Solok Regency. If the education of wife increases by one year then it will decrease the demand for tofu by 0,002 percent.

Next, the job sector of husband (formal/non formal) affects negatively and significantly on the demand for tofu in Solok Regency; if the husband works in the formal sector then it will decrease the demand for tofu by 0,265 percent. Meanwhile, the employment status of wife affects positively and insignificantly on the demand for tofu in Solok Regency; this means if the wife works in the formal sector then it will increase the demand for tofu by 0.054 percent.

\section{DISCUSSION}

\section{Analysis of consumer preferences to the processed soy products in Solok regency}

The result of the study shows that the society in Solok Regency prefer tofu and tempeh compared with other processed soy products such as tauco, soy milk, soy milk flour and beancurd. This indicates that these products can be developed as downstream products of soybean in Solok Regency. Accordingly, this means that it is necessary for the development of home industries among the farmers that aims to increase added value of processed soy products in Solok Regency.

This is consistent with the theory of consumer behavior that the behavior of consumer demand for goods and services will be influenced by several factors, among others: income, consumer's taste, and price of the goods, when other conditions are not changed (cateris paribus). This consumer behavior is based on the theory of consumer behavior that explains how a person with earned income can buy a variety of goods and services in order to reach a certain satisfaction according to what is expected.

\section{Analysis of demand of society for the processed soy products in Solok regency}

The result of the study shows that the number of household members affects significantly and positively on the demand for tempeh and tofu in Solok Regency. This means that the greater number of household members, the greater the demand for tempeh and tofu in Solok Regency and vice versa; the smaller number of household members then the smaller demand for tempeh and tofu in Solok Regency with the assumption of cateris paribus.

The education of wife affects significantly on the demand for tempeh in Solok Regency but the effect is not significant on the demand for tofu in Solok Regency.

The job sector of husband affects significantly on the demand for tempeh and tofu in Solok Regency. If the husband works in the formal sector, the demand for tempeh and tofu will decrease in Solok Regency. Job sector is closely related to the level of income received by a household so it will impact to the size of a person's demand for goods and services. This result is consistent with the views expressed by Kotler (2000) that states demand for goods and services is influenced by personal factors, namely job and economic environment. This means 
that the type of work will determine a person's decision in consuming goods and services available.

Nevertheless, income does not affect significantly on the demand for tempeh and tofu in Solok Regency. It means that the size of income level earned by a household will not give meaningful effect to changes in the society's demand for tempeh in Solok Regency. The insignificant effect of income on the demand for tempeh and tofu is caused by the relatively low selling price of tempeh and tofu so that it can be reached by the whole society in Solok Regency.

This result of study is not in accordance with the theory advanced by Case and Fair (2008) that the size of the demand is determined by income. If the goods are normal goods, the increase in society's income will cause the increase in society's demand for goods and services. But if the goods are inferior goods, the increase in society's income will decrease the demand for goods and services.

Furthermore, marital status, education of husband and job sector of wife do not affect significantly on the demand for tempeh and tofu in Solok Regency. The insignificant effect of marital status, education of husband and job sector of wife indicates that tempeh and tofu are products that are wellknown by the whole society so these products are in high demand by the society. Therefore, changes to these variables will not affect the consumer's decision to consume the goods and services available in the society.

\section{CONCLUSION}

The results of the study found that (1). The processed soy products most in demand by the society in Solok Regency are tofu and tempeh. (2) The number of household members, education of wife and job sector of husband affect significantly on the demand for tempeh in Solok Regency, while income, marital status, education of husband and job sector of wife do not affect significantly on the demand for tempeh in Solok Regency. (3). The number of household members and job sector of husband affect significantly on the demand for tofu in Solok Regency, while income, marital status, education of husband, education of wife and job sector of wife do not affect significantly on the demand for tofu in Solok Regency.

\section{REFERENCE}

Burkett, John P. (2006). Microeconomics: Optimization, Experiments, and Behavior. OXFORD UNIVERSITY PRESS: New York.

Debertin, David L. (2002). Agricultural Production Economics. University of Kentucky: Lexington.

Heien, Dale and Daniel Pick. (1991). The Structure Of International Demand For Soybean Products. Southern Journal Of Agricultural Economics July 1991.

Kastono, Dody. Pemberdayaan Petani dalam Pengembangan Kedelai Hitam. Universitas Gajah Mada: Yokyakarta. (www.google.com) diakses 1 Maret 2012.

Knipscheer, Hendrik C dkk (1982). Demand Elasticities fo Soybean Meal in the Eoropean Community. American Journal of Agricultural Economics Vol. 64, Issue 2, page 249 253.

Mujahidin, Endin, Muarif, dan Dedeh Yuliah. Pemberdayaan Masyarakat Miskin Di Desa Palabuhanratu: Kajian Pengembangan Model Pemberdayaan Masyarakat Miskin Di Wilayah Pesisir Pantai. (www.google.com) diakses 1 Maret 2012. 
Nazaruddin (2012). Pedoman Teknis Pengembangan Agroindustri Tanaman Pangan Tahun 2012. Direktorat Pengolahan Hasil Pertanian Direktorat Jenderal Pengolahan Dan Pemasaran Hasil Pertanian: Jakarta.

Nicholson, Walter, (2005). Microeconomics Theory: Basic Principle And Extensions, International Student Edition, Ninth Edition, Thomson South Western, New York.

Pearloff, M. Jeffrey, (2012). Microeconomics, Global Edition, Sixth Edition, Pearson, New York.

Putra, Angga Pratama Hardiansya. (2009). Pemberdayaan Petani Dalam Rangka Pemantapan Ketahanan Pangan Nasional. (www.wordpress.com, diakses pada tanggal 01 Maret 2012)

Rasmussen, Svend. (2011). Production Economics: The Basic Theory of Production Optimisation. Springer: New York.

Simatupang, Pantjar, Dewa K.S. Swastika, Muhammad Iqbal. dan Iwan Setiadjie. Pemberdayaan Petani Miskin Melalui Inovasi Teknologi Pertanian Di Nusa Tenggara Barat. Pusat Penelitian dan Pengembangan Sosial Ekonomi Pertanian. (www.google.com) diakses tanggal 3 Maret 2012.

Syahza, Almasdi (2002) Pengembangan Usaha Kecil Dan Menengah (Ukm) Untuk Percepatan Peningkatan Ekonomi Daerah Di Kabupaten Indragiri Hulu Propinsi Riau Pusat Pengkajian Koperasi dan Pemberdayaan Ekonomi Masyarakat (PPKPEM) Universitas Riau.

(2003). Rancangan Model Pemberdayaan Ekonomi Masyarakat Pedesaan Berbasis Agribisnis di Daerah Riau (Modeling Of Economic Empowerment Of Rural Community Based On Agro-Business Activities In Riau). Pusat pengkajian koperasi dan pemberdayaan ekonomi masyarakat (ppkpem) Universitas Riau.

Yamaura, Koichi. (2011). Market Power of the Japanese Non-GM Soybean Import Market: The U.S. Exporter VS. Japanese Importers. Asian Journal of Agriculture and Rural Development, 1(2), $80-89$. 